\title{
CULTURAL IDENTITIES IN SUSTAINING RELIGIOUS COMMUNITIES IN THE ARCTIC REGION: AN ETHNOGRAPHIC ANALYSIS OF RELIGIOSITY FROM THE NORTHERN VIEWPOINT
}

\author{
NAFISA YEASMIN \\ $\mathrm{PhD}$ Candidate, Researcher \\ Arctic Governance Research Group \\ Arctic Centre \\ University of Lapland \\ PL-122, 96101 Rovaniemi \\ e-mail: nafisa.yeasmin@ulapland.fi
}

\begin{abstract}
Northern countries are facing the challenges of declining human capital, and admitting immigrants, many of whom belong to religious minorities, to satisfy the demand for labour. If northern societies accept multiculturalism and immigrants, they should not disregard the cultures and religious practices (for example, ritual slaughter) of immigrants, as they need to survive and integrate as a minority community in a secular society. However, there is clash between secularism and religions permitting animal slaughter, which is prohibited by some and allowed by other European countries. Community viability and sustainability depend partly on the exercise of community beliefs and ideology that support identity behaviour. This study will present an ethnographic analysis of the religiosity related to ritual slaughter and Muslim cultural identity in the European Arctic region and explore how religious relativism and practice sustain the community and support the overall integration of the Muslim minority in the North.
\end{abstract}

KEYWORDS: religious practice $\bullet$ community $\bullet$ sustainability $\bullet$ North $\bullet$ identity $\bullet$ religious minority

\section{INTRODUCTION}

Small communities in a dominant society are always vulnerable groups. The North is a sparsely populated area in which human capital is declining. Circumstances highlight the importance of making small communities viable and sustainable by effective communication with the dominant society, by community commitment and by group effort across and within communities. There is considerable potential in determining the common features of small communities and affording them common sources of livelihood and opportunities to practice their cultural activities (Larsen and Fondahl 2014). In this paper, I will discuss the cultural and religious sustainability of Muslim communities in the context of ritual slaughter as an instance of relativism. This paper also explores how religious and cultural factors affect the well-being of religious communities and 
community cohesiveness (see also Yeasmin 2014). I have chosen ritual slaughter as a religious belief and aspect of the cultural identity of religious minorities and as a factor that helps religious minorities be viable as communities in the North. In this connection, I also discuss animal welfare ethics from secular and religious perspectives.

Ritual slaughter means the slaughter of an animal according to a faith. It is a collective action of community members to ensure that the community will get meat that is pure, wholesome and suitable for health. Instead of using industrial methods, a ritual slaughter is carried out by believers until the death of the animal. Within Islam this cultural action must be done by a mature Muslim in order to maintain the human-animal relationship (Downing 2015: 4). Ritual slaughter by Muslims involves slitting the throat of the animal and draining the blood in line with religious customs while the animal is still conscious (Gradin 2010). A problem here is that ritual slaughter without stunning is prohibited by law in northern countries (FAWA 33b). Some believers among religious minorities are of the view that the perceptions of animal slaughter are largely based on emotional values in these societies (Valenta 2012). According to the planned behaviour theory, immigrants try to cope with the environment they find when arriving in the host country. However, low levels of interaction with the majority society, confusion and misunderstandings, uncertainty in the labour market, and extreme weather creates social pressure. Immigrants try to find their identities and individual beliefs during this transition period. They feel a belonging to a certain group and accept a certain behaviour that conforms to the norms of that group. Subjective norms are a function of the beliefs of individuals (Bonne et al. 2007). Their perceived behavioural control suppresses the performance of behaviour intentions. Food comes first as part of cultural identity, since it is a daily and basic need - immigrants consume identity through food. Thus, attitude, subjective norms and perceived behavioural control are constituents of intention when consuming halal food. (Hall and Sevim 2016)

According to Geert Hofstede (1984: 81-99), management is man-made and people engage in it according to their own values and interests, with dominant values given priority within a culture and community. In this paper I point out that practicing freedom of religious practice is a vast field of research, even practicing religious freedom does not have a dominant value in a community in the same way that human rights do. However, every religion takes a position on animal ethics and animal welfare figures prominently in Judaism and Islam (through the Qur'ân). Religious minorities are concerned with efforts to protect animal rights. Similarly, they believe that ritual slaughter is conducted in the least painful way, without unnecessary suffering, and is the quickest death. (Sehada 2009; Rahman and Aidaros 2012) Muslims also believe that stunning an animal before slaughter causes unnecessary pain, which is unethical.

Muslims cannot form native communities in the North. They have emigrated from Asia - both the Near East and Far East - and Africa and are the minority among a minority. The North is a sparsely populated area and full of challenges and hopes. The northern countries need skilled and low-skilled immigrants to meet the demand for labour (Yeasmin 2014; 2016). The northern region is vulnerable to climate change and relies on only a few economic sectors. Thus, the region needs different communities from outside for social collaboration and cohesion. Diversity could be a source of strength for northern societies as a whole (Giordan 2014; Larsen and Fondahl 2014).

Several studies indicate clearly that the North needs to attract young immigrants and retain a skilled workforce, as demographic decline is one of the biggest challenges 
that the region faces (Yeasmin 2016). Religious communities are rather vulnerable, as they face problems in practicing the faiths and cultures that give them strength (Yeasmin 2014). ${ }^{1}$ Lack of opportunities to interact with locals, labour market exclusion and social exclusion are all barriers to Muslims practicing their own culture and religion and this to some extent constitutes a barrier to the immigrant minorities integrating properly. Communities are very small in number but increasing all the time while the cities welcome quota refugees each year. Most of these refugees are from Muslim countries, although still the percentage of Muslims is small and they are scattered throughout the region. On the basis of planned behaviour theory and this ethnographic study, Muslims also believe in maintaining their cultural faith and maintaining social cohesion within the community.

According to Muslims, ritual slaughter has cultural and religious significance. In principle, the practice of ritual slaughter creates binding requirements for a certain group of people with a particular faith. It is difficult for immigrant religious minorities to survive in the North, as geographical remoteness and lack of knowledge about the host society tend to isolate them in this part of the world. Religious minorities who come from outside the region face problems in practicing their livelihoods. Food identity as an integral part of a wider culture facilitates the process of integration, well-being and survival. (Stajcic 2013: 8) Many European countries have abolished ritual slaughter, although a derogation permitting it is found in Article 10 of the Charter of Fundamental Rights of the EU (Downing 2015: 8). The abolition of ritual slaughter restricts food consumption. Halal food practices validate Muslim truths: their forms of slaughter are equally, or more, conducive to animal welfare than normal methods based on science and modern industrial technology (Valenta 2012: 30).

For the purposes of integration, traditional people among religious minorities around the world try to maintain close ties with their cultural and traditional knowledge, which is important for the management of society (Almerico 2014; Burack and Schmidt 2014). Collaborative management approaches are needed to secure the exercise of religious customs and cultural rights, strengthen community organisations and generate livelihoods from well-managed resources (Burack and Schmidt 2014; Stevens 2014). This article examines the integration and assimilation of minor religious communities into the majority and dominant community in the North, where societies are very much based on community identity. According to the Qur'ân, consuming halal meat is a significant aspect of community identity among Muslims. This study explores why ritual slaughter is potentially important to keep cultural identity among Muslims in terms of the human-animal relationship. The author also argues that the animal ethics associated with slaughtering in the modern way constitutes a political agenda which gives no allowance for faith and the challenges of maintaining community sustainability. The study followed qualitative methods of ethnographic study.

\section{STUDY METHODOLOGY}

Ethnographic observation was conducted in the 2013-2016 period. The author spent these years with immigrant communities in the northern cities of Finnish Lapland, Northern Ostrobothnia (the Oulu and Kainuu region; 2013-2016) and Luleå, Norbotten in Sweden (2013). 


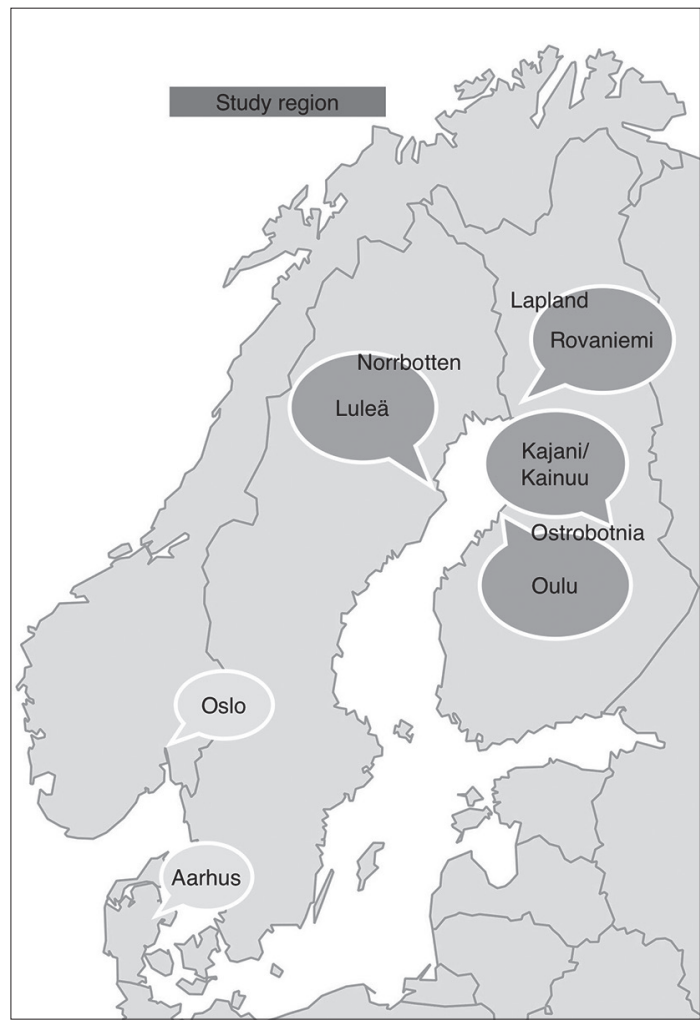

Figure 1. Map of the study region. Image by the author.
These regions are full of natural Arctic resources, but the labour market offers better opportunities in Norbotten than in Finnish Lapland and Ostrobothnia. The unemployment rate among immigrants in Finnish Lapland is about 30\% with Muslim in a vulnerable position in the labour market. Ninety percent of informant families are out of the labour market and several of them are longterm unemployed. They depend on social welfare benefits. Some of them work partly in pizza shops despite having professional backgrounds and educations. This research began by observing the increasing number of religious immigrant group in those cities. They are Muslim refugees who are facing challenges with the viability of their community and getting access to halal food in the North. The practice of religion is an emblem of their identity.

Unstructured data was collected from direct engagement through informal conversations, community meetings, individual family histories, and through my involvement with their

daily activities to some extent. Some other religious communities such as the Baha'i, Mormon, Catholic, Orthodox and Pentecostals (Yeasmin 2014) took part in in-depth interviews. The other religious communities were interviewed to identify the role of religiosity in determining the cohesion and integration of minorities. However, as a case study I have chosen Muslim minorities and their cultural identities in practice.

In data analysis, the study emphasises and categorises themes and key issues. The main themes are narrated in accordance with theoretical explanations based on empirical insights. After triangulation of data, the study highlights the data that relates to the integration of the Muslim community in the North and how integration related to the religious and cultural identities of Muslim minorities. The data collected from interviews of other religion minorities also suggests that religiosity can facilitate and open up nodes of integration (Yeasmin 2014). The Muslims under observation for the study are from Palestine, Iraq, Iran, Somalia, Afghanistan, Turkey, Bangladesh, and Pakistan. The Islamic denomination of one informant family is Shia and another Ahmadi. The rest are followers of Sunni Islam.

The theological aspects and argumentation relating to cultural identity as part of sustaining community have been outlined in the literature review below. The social values of a diverse community are a combination of a miscellaneous set of human needs. Ensuring a quality of life for all segments of the population is one aspect of social sus- 
tainability that encompasses all kinds of human rights and social justice with human dignity. The data and empirical materials from ethnographic observation is assessed and argued based on existing concepts and theories.The data and material from ethnographic observation is justified by the concepts and theories of the philosophy of human mind in sustaining community. A motivated human behaviour could be the cause of prior satisfaction or dissatisfaction to control humans' ultimate or basic goals rather than partial or superficial ones. (Maslow 1943). The basic and unconscious goals of Muslims in their customary notions about moral relativism towards animals come as a psychological need that encourages them to be integrated into a host society (ibid.).

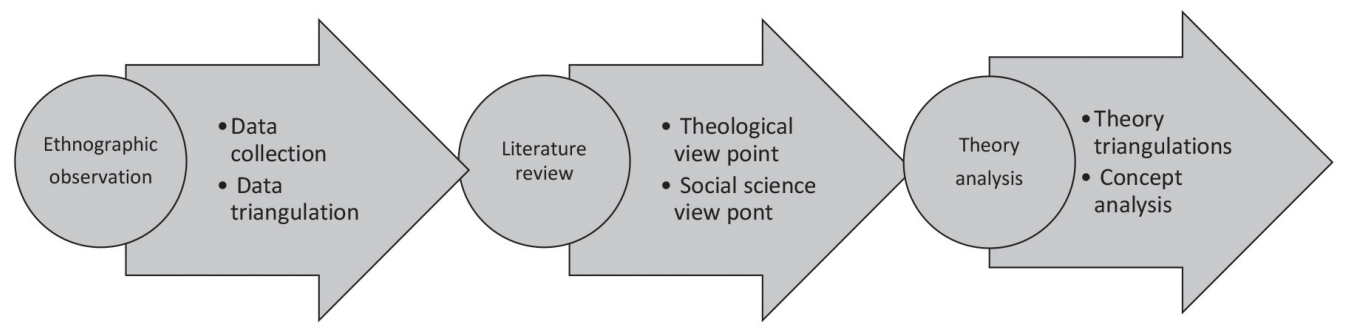

Figure 2. Research Process. Image by the author.

\section{PERCEPTIONS OF SLAUGHTER: LITERATURE REVIEW}

In modern society, slaughter without stunning is considered cruelty to animals: modern emotions require that all animals should be made unconscious by stunning prior to slaughter. In contrast, according to religious belief, stunning involves unnecessary pain and suffering for an animal. The different methods of stunning that have been identified over the years as causing stress for animals include electric stunning, casting with a rope, hoisting by hind legs, half inversion in a rotary pen, full inversion in a rotary pen, restraint while standing upright and carbon dioxide stunning (Gregory 2005; Grandin 2010; 2013; Lambooij et al. 2012a; 2012b). Stunning before slaughter is inhumane to animals. Carbon dioxide stunning is used to stun pigs in many countries. The method irritates the respiratory tract (Becerril-Herrera et al. 2009 ) while the animal is still conscious and increases the anaerobic oxidative metabolism, which in turn causes glucose levels to rise in the blood stream (Becerril-Herrera et al. 2009; Nakyinsige et al. 2014 ). It cannot be ethical to cause extra pain and stress to animals (Grandin 1992). Electric stunning of cattle has been successfully used in many countries. It is a two-stage method in which the first stun is designed to stop the heart and the second one the brain. Grandin's study shows that immobilisation of conscious, sentient animals is very detrimental to animal welfare (ibid.)

All methods of slaughter cause stress, fear and pain in animals. According to Irwin H. Putzkoff and his colleagues (2012), stress causes several disease processes in humans who eat the meat. Slaughter preceded by stunning causes stress in animals and the production of stress-induced hormones and corticoids, which are harmful to human health. Most of the methods of stunning affect critical blood constituents such as cat- 
echolamines, lactate, glucose, calcium, magnesium, and proteins (Becerril-Herrera et al. 2009; Nakyinsige et al. 2014). According to Nakyinsige et al. 2014, stunning before slaughter can reduce the stress associated with slaughter. However, these changes may not in fact translate into an improvement in animal welfare (ibid.). Other research also finds that it is good for animal welfare to reduce as much as possible the waiting period for pigs between the time they leave the stunning chamber and death (Bolaños-López et al. 2014) as they have psychological responses after stunning as well. In sum, it is good to slaughter animals as fast as possible.

On the other hand, according to Muslim dietary prescriptions, ritual slaughter without stunning is a less painful way and death is quicker than in modern slaughter practice. It is an ethical way to slaughter an animal. In halal, slaughter requires a sharp knife, as well as a trained Muslim man who can slaughter the animal in one attempt by cutting its throat in the name of Allah. This fast method causes the animal no pain and brain function is lost immediately (Levinger 1995; Rosen 2004; Qur'ân, Surah 2:172173 and Shechita). Accordingly, the animal cannot suffer for a long time and bleeding should be complete (Nakyinsige et al. 2013). Pre-stunning is accepted by some Muslim authorities (see Salamano et al. 2013), for example in Turkey and Malaysia. They have some requirements, such as the animal should be alive at the moment of slaughter (Anil 2014). However, on the other hand, some other groups of Muslims do not accept this, so it is a controversial issue. Some Muslims believe that the animal suffers if the transition between stunning and death is long (Nakyinsige et al. 2013) and that extra suffering is caused by pre-slaughter handling of animals (Anil 2014).

\section{THE EVALUATION OF INTEGRATION AND \\ RELIGIOUS PRACTICES}

The sociology of religion is the most significant factor that influences whether immigrants are integrated into the host society. Religion can become more and more important in a phase of an individual's life when he or she faces great social change in a host country (Berry 1997; Baumann 2002; Borup and Ahlin 2011; Pace 2014; FM 2016). The possible relationship between religion and social integration varies according to adaptation perspectives (Borup and Ahlin 2011; FM 2016). Successful and sustainable integration depends on institutional arrangements, religious engagement, type of religion and the general relationship with the host culture, as well as the geographical location of the minority (Borup and Ahlin 2011; Yeasmin 2017). Coexistence of different ethnic and cultural groups entails awareness of identity, persistence of relationship, the concept of communal society and participation in civic activities. Anti-immigrant discourses based on ethnicity and an imbalance between the religiosity of the immigrant and the native hinder any eagerness to participate in mainstream society (Cesari 2013), even though many factors other than tolerance of the religiosity of the immigrants also affect harmonious coexistence (Reed et al. 2013; Shameem et al. 2014). There are many other options and opportunities to increase quality of life, for example adaptive management, transition management, social learning and earning, social inclusion, equivalence in cultural activities and cultural identity (FM 2014-2016; see also Figure 3). 


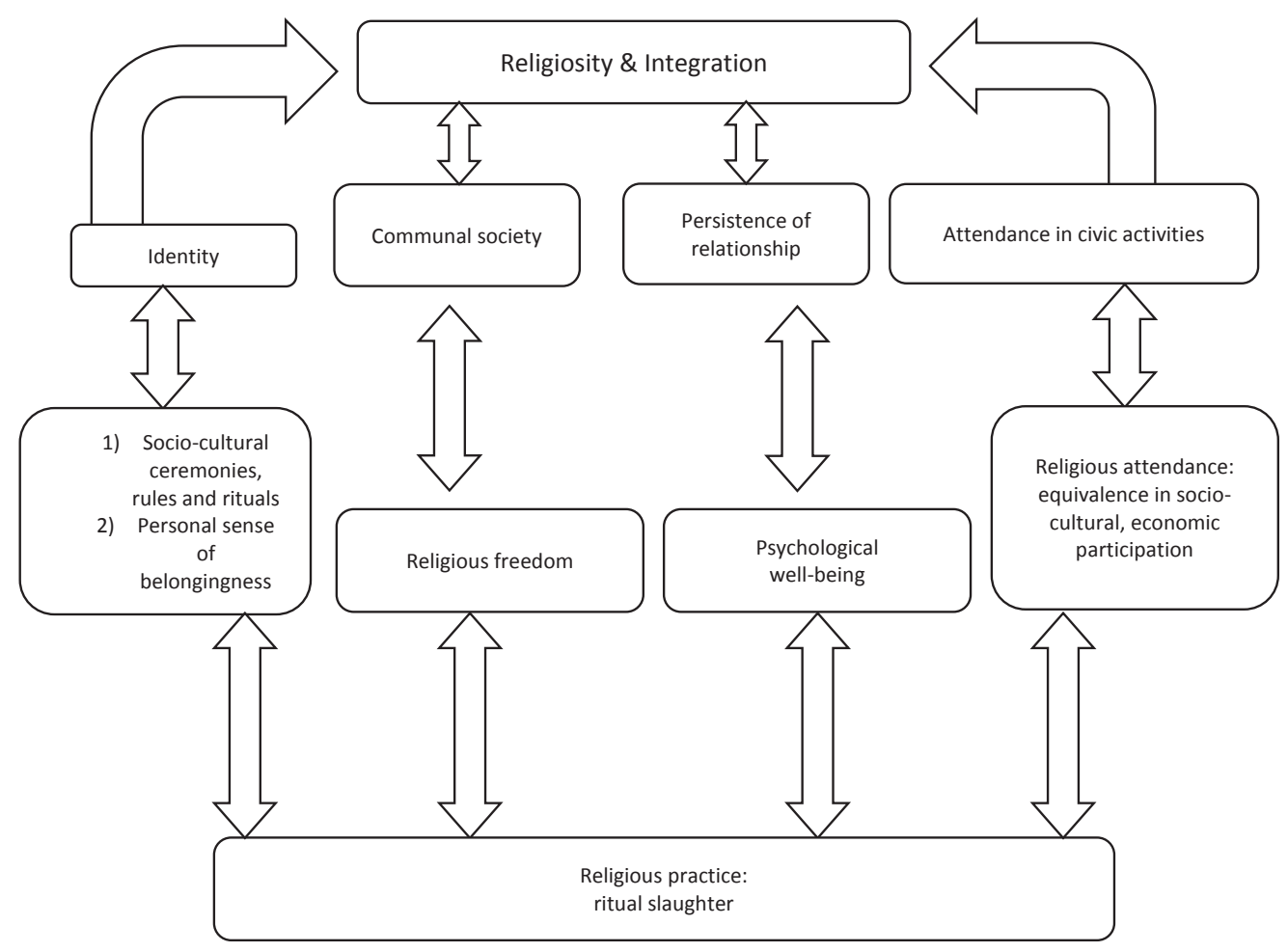

Figure 3. Religious practice facilitates integration. Source, author elaboration from FM 2014-2016.

Some important factors like extreme cold, social exclusion, socio-economic status and identity crisis influence informants to adopt different adaptation strategies in the North (Reed et al. 2013). Vulnerability of livelihoods affects a community's micro level livelihood options (Singh and Gilman 1999).

\section{THE NEED-BASED THEORY OF MOTIVATION}

Muslims in the North try to integrate themselves through religious practice and cultural activity. Food as a daily need is a priority and the need for halal food became an issue of food security. According to Abraham Maslow's (1943) hierarchy of needs theory (see Figure 4), needs such as food, water and other biological needs are psychological. Although these needs are basic, they become more urgent when someone is lacking these resources and is searching for them. From the Muslim point of view people tend to become concerned about food safety based on Islamic dietary instructions. This later becomes seen as a social need related to religious and cultural practice. Social exclusion pushes them to think about their identity as a matter of self-esteem. Ultimately these needs manifest themselves and bring new challenges to ritual slaughter. 


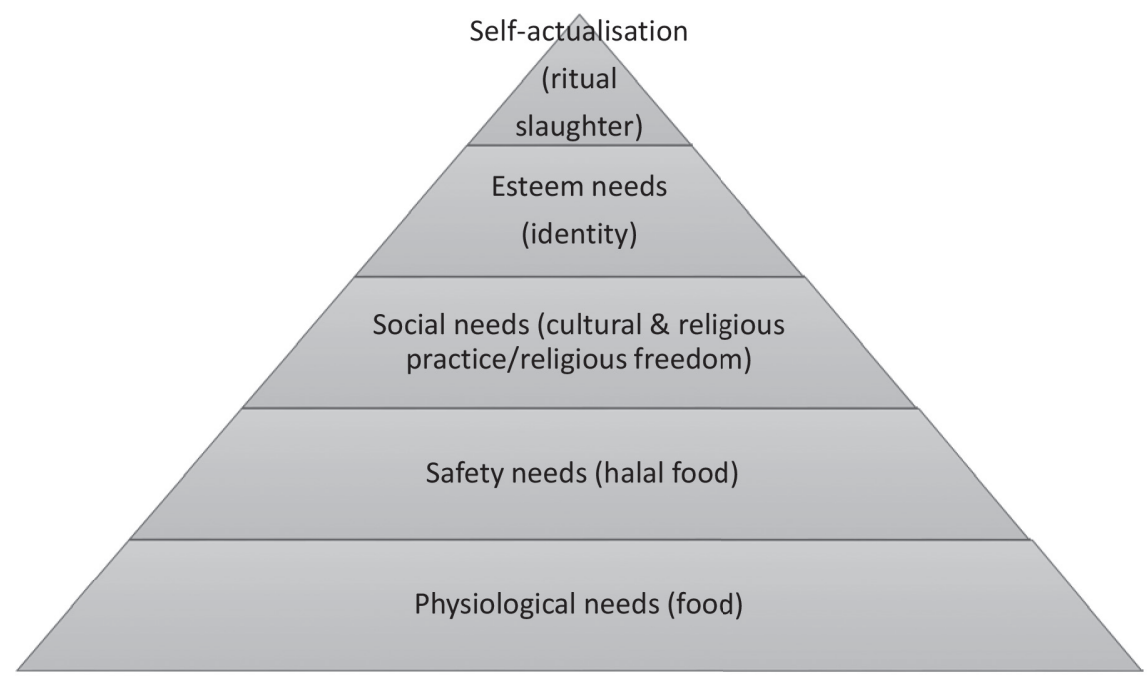

Figure 4. The need-based theory of motivation. Maslow's (1943) hierarchy of needs combined with the author's fieldwork materials from 2014 to 2016.

However, in light of Hofstede's (1984) value dimension of community belief, and Edward Hall's (1966; 1976) findings on geographical location, consumer demand and the context of community sustainability, it would make sense to protect ritual slaughter to maintain cultural and religion diversity and freedom.

Muslim cultures vary from country to country, although to encourage participation and avoid social isolation Muslims from different countries try to put aside their differences and form a community bond, finding micro-level livelihood options. Peer involvement through ritual slaughter is an effective indicator of informants' beliefs and sensitivities towards their community and the potential to organise and mobilise for collective action (Kavanaugh et al. 2007; Brunton-Smith et al. 2014). Halal food is considered safe for Muslims to eat. However, as the literature review below indicates, ritual slaughter considerable significance for the cultural and religious beliefs of a particular community, a finding which is strongly supported by the holy book, the Qur'ân. Ritual slaughter is part of the worldwide Muslim religious festival that takes place after the pilgrimage to Mecca. Religious minorities believe that collective social action and ritual slaughter are part of social collectivism. Thus, ritual slaughter has a significant value in Islamic culture, where it is a form of animal assisted mental therapy. (FM 2013-2014) Some herders have the opportunity to slaughter sheep, which is generally a hidden practice according to some informants and unknown to others in Finnish Lapland. Ritual slaughter is a facet of the human-animal bond and forms part of spiritual belief as it relates to human health and wellbeing. (FM 2014) Muslims demonstrate the collective viability of their religion through ritual slaughter. Those who have the opportunity to slaughter, practice it even though it is difficult, illegal and more expensive than buying commercial non-halal meat. They would like to handle the animal themselves, show respect to the animal and apologise before the act of slaughter. Although they use prestunning, they are satisfied. The only problem is that they only have this opportunity 
during the summer. Slaughtering the animals is a collective action for some families, they ritually slaughter together if possible. Ritual slaughter is a social means for and collaborative source of interaction between people and society. Rituals of a religious community encourage people to engage with one another in similar environments in a similar manner. (FM 2014) Many of the similarities in codes, conduct, rituals, and folklore are the result of cultural interactions (see Bledsoe) that could ensure the viability of particular religious communities, for example the Sami indigenous community, and the Jewish community.

Above all, the motivation for having halal meat is animal welfare. Animal rights are an example of animal ethics. Scientifically, there is no universal truth in ethics (Hinman 2003). Accordingly, the standards by which scientists make their decisions on animal ethics is also diverse and interpreted diversely when applied to different cases. Ethics pertaining to animals depends on different issues, for example, a healthy animal population or ecosystem, and so on (Fraser 1999). Different ethics are also applied to farm animals and wild animals. Many of our practices focus attention on our needs, demands and societal values. Some of the societal issues get attention because of the appeal of cultural relativism. Many of the social practices and attitudes that we think of as natural law are only cultural products. Every society should try to keep this in mind if we are to avoid being arrogant and want to have open minds towards such community beliefs. (Hinman 2003)

Nevertheless, every community expresses moral concern about animals and identifies the significance of empirical analysis in decisions about animal practices (Fraser 1999). Islamic communities are not unanimous on the modern approach to slaughter. Severe doubts exist among enough followers of Islam (and Judaism) about accepting the current approach to slaughter, which necessitates animal unconsciousness by prior stunning (Schyff 2014). There is a preconception about the rights and wrongs of ritual slaughter in the member states of the European Union. In fact, where ritual slaughter is allowed, it can be seen as historical recognition of religion in the contemporary secular political world (Valenta 2012). This is particularly important because it is religious minorities that are affected when ritual slaughter is banned, which is not a suitable way to integrate such minorities into European host societies. Some Muslim people south of the Arctic collectively work for northern Muslims, and slaughtered animals in Estonia are distributed among Muslims residing in the North (FM 2014), since according to the peoples of the North ritual slaughter is not banned in Estonia. Halal food was not available in some cities in the North, especially halal beef, and halal reindeer is also rare. Therefore, some Muslim families collect halal food from other bigger cities where it was available (FM 2013). For instance, some families from Rovaniemi collect halal foods from the next city, Oulu (about $250 \mathrm{~km}$ south), or from Luleå (in Sweden) (FM 2013). Even if some of the families do not have any knowledge of human-animal relations in Islam, they just follow the basic and unconscious goal of eating halal food (FM 2015). Although there is now a halal food shop in Rovaniemi, Muslims are not satisfied as all halal food is not always available in the shop and there is doubt about the quality of frozen meat. The taste of the frozen meat also differs from fresh meat. Sometimes they have to wait for a long period to get some halal food since the transnational supply of halal meat is not frequent. (FM 2016) Therefore, a few Muslim families consume locally produced non-halal meat both for food safety reasons and because of the irregular sup- 
ply of the halal product. According to their interpretation a Muslim can consume nonhalal if nothing else is available; the people who follow this interpretation are generally Ahmadi. On the other hand, Ahmadi also believe that by whispering Qur'ânic words at the time of cooking or processing they are permitted to consume non-halal meat. This is indeed controversial among informants.

\section{COMMUNITY SUSTAINABILITY IN THE STUDY REGION}

Ritual slaughter is a matter of religious freedom for minorities. It is argued by many concerned Muslims in the region that this dilemma is a barrier to practicing religion in the North and a hindrance to community viability and sustainability. Muslims who are refugees practice religious culture more actively than for example Muslims who arrived as students. Muslim refugees are growing in number in the region. On the other hand, the local working-age population is declining as the population ages and the youth move to the southern parts of the countries seeking better opportunities. Members of small religious communities are moving from or within their region, from city to city looking for comparatively larger religious communities of their own (Yeasmin 2014; FM 2014 Catholic church).

Statistically, the overall net figures of internal and international migration are negative for the North. Finnish Lapland, for example, has been losing around 1,000 inhabitants per year in recent years (Finnish Statistics 2012). The European North thus needs immigrants for future economic development of the region and to address the emerging labour shortage as the local workforce declines (Yeasmin 2013; 2014). Economic activities in the region are diverse and regional development depends on Arctic fishing, underground technology, oil and gas extraction, mining, forestry, reindeer husbandry and the tourism industry (Röver 2014). The North is a developing region that needs extra human capital for the exploration and exploitation of gas and energy, with no less than $80 \%$ of the world's technology for underground mining expected to come from the Norwegian and Russian North (Bildt 2011). An influx of people means rising demand, innovation and diverse new ideas. Social networks and group thinking develop common values and comprehensive visions (Luthe 2014). If it is to achieve sustainable development, the region needs to attract minorities who will stay there. 

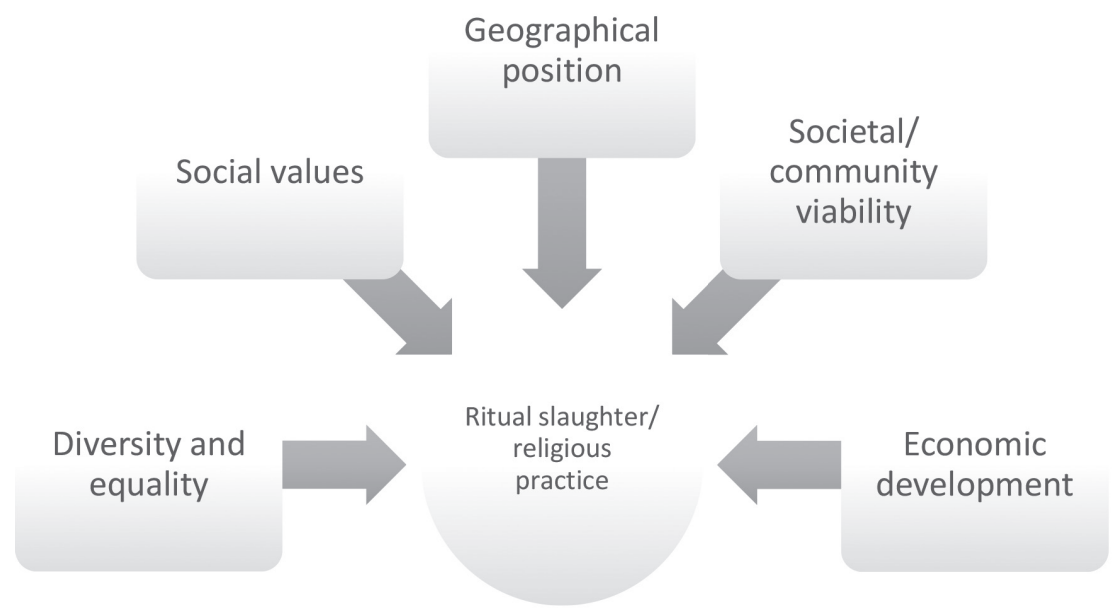

Figure 5. Religious slaughter in the context of societal sustainability. Image by the author.

Figure 5 depicts the role of ritual slaughter within the broader context of sustainable development. The issue of sustainability has been approached through a variety of conceptual frameworks and tools (Fiksel 2006; Zhang and Bakshi 2010; Burns 2012). It has value for sustaining small minority communities in the North, which are geographically isolated in global terms, and is thus crucial for the northern economy, which depends on human capital from outside the region (Larsen and Fondahl 2014). Diverse religious communities rely on their religious and spiritual norms, beliefs, and practices to cope with difficulties, challenges, and stressors in the host country (Edgell 2012; Diller 2014; Hisham and Pargament 2015). Religious practices can offer a sustainable framework for adjusting to many other important dimensions of a new host society, such as diversity, equality, social justice and intercultural competency (Kolan and Sullivan TwoTrees 2014).

Sustainable development focuses on three major pillars: boosting the economy, protecting the environment, and promoting social equality. Critics argue that Arctic policies are often at best developed for the people of the North (Röver 2014). My study argues that religious communities should not be overlooked in Arctic policies. Social equality should be ensured in the case of religious communities in the region. The region should provide equal treatment and development policies for all religious and immigrant communities as minorities. A variety of development projects have been put forward to move the region towards more sustainable development (Atkinson 2004). Religious communities must be developed likewise. In this transitional situation, human interests based on religion and tradition can override animal interest at least as it relates to their suffering.

There is a lack of knowledge in northern society of religious animal welfare. The main concerns of Muslims are to get meat and food conforming to their religious dietary prescriptions. Allowing the exercise of religion among immigrants in the North has considerable value in the accommodation of new minorities, which can contribute to the increase in population needed and boost the region's economy, helping to solve its 
demographic challenges (Yeasmin 2014). I argue that ritual slaughter is a cultural freedom and strongly supports the acculturation process in the North. Apparently, integration is a more suitable term than assimilation when dealing with religious communities (Jupp 2011). Religion is one of the measures used to determine the status of immigrants. Religious discrimination does not encourage immigrants to be integrated in and commit themselves to their host societies. Supportive integration strategies reduce immigrant involvement in crime and increase the involvement of immigrants in the host society. As many previous studies have argued, a sense of belonging and citizenship stops them joining negative social cliques and from engaging in criminal behaviour (Ngo et al. 2017)

If northern societies accept immigrants and multiculturalism, they should not ignore the culture and religion of immigrants. Immigrants form minorities that desire to survive and integrate into secular communities.

In the North, religious communities find their identity by practicing religion. Northern minority communities need the kind of mental support that would motivate them to take responsibility for a sustainable future. They need collective engagement with other communities to create the conditions for a sustainable economy (Yeasmin 2014). Local communities need knowledge and information about what can be done at the local and regional levels to preserve and protect the environment, nature and human capital in the Arctic region (Rasmussen and Olsen 2014).

If they are to respect human rights, establish democracy and ensure religious freedom and equality, societies in the North should become more tolerant and welcome religious minorities (Barna 2014). However, animal rights come before human rights in the cases of Norway, Denmark and Sweden, which have banned ritual slaughter (Barna 2014; Lavi 2014). Finland requires post-cut stunning (Lavi 2014; Schyff 2014). Slaughterhouses need to apply stunning before slaughter according to the law. On the other hand, Finland's current Animal Welfare Act (FAWA 33b) requires that in religious slaughter animals should be stunned and bled simultaneously. There is hesitation about ritual slaughter in Sweden. In any event, meat can be found in markets in the North with the label "halal meat" on the package. According to the merchants, the meat comes from Sweden, which prompts the question how is this halal meat produced, and how ethical this kind of business is if ritual slaughter is banned in Sweden? Sweden is losing credibility in halal meat production.

Secularists have said nothing about how unethical false labelling is towards believers. Muslims in the southern parts of northern countries somehow succeed in importing halal meat with the help of other Muslim communities in nearby countries where the law permits ritual slaughter, for example, Estonia and Germany. However, Muslims in the North face problems with halal meat due to their geographical location. Some Muslims in the North accept pre-slaughter stunning if the animal is still alive at the time of slaughter, while other Muslim communities in the region do not accept pre-stunning. In a similar way pre-stunning is not allowed in kosher slaughter, so this practice is not currently possible in Nordic countries due to animal welfare regulations, which thus raises questions of religious rights and religious discrimination.

The region has plans to enhance its business cooperation with non-Arctic partners from China, India, South Korea and Singapore (Röver 2014). Therefore, equal socioeconomic and religious access and participation in the host society for all communities 
could attract stakeholders from outside to invest in the region. It should be noted that Islam is the second largest religion in India and Singapore, practiced by about $15 \%$ of the population in both countries; ritual slaughter is permitted in both places.

\section{CONCLUSION}

The human-animal relationship offers a psychological framework that casts light on the dominant society, minority communities and individual believers. I have found that ritual slaughter is a psychological facet of the attachment between religious believers and animals. In this study, the human-animal relationship was assessed by discussing religious believers' attitudes towards slaughter and the importance of such attitudes in religious belief. The findings of this paper indicate that the human-animal relationship is relevant and could support community sustainability in the region.

This is a conflict area between animal rights and human rights: on the one hand, there are considerations of freedom of religious practice, on the other, animal welfare in secularism. This is a big issue that should be considered in the region. It is a conflict between religious and secular values as well. However, it is critical to point out that it is not possible to find the truth or measure the truth of religious believers' and secularists' emotions by the methods of science. It is an ethical issue that cannot be settled by any universal and absolute prescription. As a particular method of truth finding, science itself has no social and political values that could serve all interests, positions and projects (Valenta 2012). A minority community is part of society and prohibiting ritual slaughter is a dubious intervention in the religious identity of minorities in northern countries. As Markha Valenta (ibid.) has stated, religious minorities do not have strong political representation through which they can provide voters with factual and practical knowledge about ritual slaughter. In a society, people of all beliefs should have equal treatment before the law, and the rights of those with all beliefs to hold and live by these beliefs should be reasonably accommodated within a legal framework, which should set minimum common legal standards (BHA 2012: 2).

How can protection of animals at the time of killing take precedence over human beliefs and the sustainability of a community and human rights (ECHR; Zoethout 2013)? This protection is in any case not for the lives of animals, but for animals that will be slaughtered for human consumption. It is not a topic of ethics to make pronouncements about animal welfare at the time of killing an animal. There is a spiritual bond between humans and animals in religious relativism. Ritual slaughter is still not an issue that is debated in the North, as the religious groups are minority communities and try to solve their problems within the communities (Yeasmin 2014). However, the issue of ritual slaughter relates to human rights and the integration of religious communities in the North. These concerns should be addressed within any strategy for the sustainability of community management in the North.

\section{NOTES}

1 Yeasmin 2014 encompasses 4 northern municipalities in Northern Finland and Sweden. 


\section{SOURCES}

FM $=$ Fieldwork material has been collected through ethnographic observation between 2013 and 2016 within immigrant communities in the northern cities of Finnish Lapland, Northern Ostrobothnia (Oulu and Kainuu region; 2013-2016) and Luleå, Norbotten in Sweden (2013).

\section{REFERENCES}

Almerico, Gina M. 2014. Food and Identity: Food Studies, Cultural, and Personal Identity. - Journal of International Business and Cultural Studies 8. www.aabri.com/manuscripts/141797.pdf (accessed November 30, 2017).

Anil, Haluk M. 2014. Religious Slaughter: A Current Controversial Animal Welfare Issue. - Animal Frontiers 2 (3): 64-67. DOI: https://doi.org/10.2527/af.2012-0051.

Atkinson, Ken. 2004. Sustainable Futures for the Arctic North. - Exploring Sustainable Development: Geographical Perspectives, edited by Martin Purvis and Alan Grainger. London: Earthscan, 229-249.

Barna, Maxwell. 2014. Ritual Slaughter Ban Supposedly Puts Animal Rights Before Religion. Vice News. https://news.vice.com/article/ritual-slaughter-ban-supposedly-puts-animal-rightsbefore-religion (accessed November 30, 2017).

Baumann, Martin. 2002. Migrant Settlement, Religion and Phases of Diaspora. - Migration: A European Journal of International Migration and Ethnic Relations 33/34/35: 93-117.

Becerril-Herrera, M.; M. Alonso-Spilsbury, C. Lemus-Flores, I. Guerrero-Legarreta, A. OlmosHernández, R. Ramírez-Necoechea and D. Mota-Rojas. 2009. CO 2 Stunning May Compromise Swine Welfare Compared with Electrical Stunning. - Meat Science 81 (1): 233-237. DOI: https:// doi.org/10.1016/j.meatsci.2008.07.025.

Berry, John W. 1997. Immigration, Acculturation, and Adaption. - Applied Psychology: An International Review 46 (1): 5-34.

Bildt, Carl. 2011. Report of the Swedish Chairmanship of BEAC 2009-2011. - Barents Euro Arctic Council.http://www.barentsinfo.fi/beac/docs/All_speeches_13th_BEAC_Ministerial_Session_ Kiruna_12_October_2011_upd2011-10-27.pdf (accessed January 12, 2013).

Bolaños-López, D.; D. Mota-Rojas, I. Guerrero-Legarreta, S. Flores-Peinado, P. Mora-Medina, P. Roldan-Santiago, F. Borderas-Tordesillas, R. García-Herrera, M. Trujillo-Ortega and R. Ramírez-Necoechea. 2014. Recovery of Consciousness in Hogs Stunned with $\mathrm{CO}_{2}$ : Physiological Responses. - Meat Science 98 (2): 193-197. DOI: https://doi.org/10.1016/j.meatsci.2014.05.034.

Bonne, Karijn; Iris Vermeir, Florence Bergeaud-Blackler and Wim Verbeke. 2007. Determinants of Halal Meat Consumption in France. - British Food Journal 109 (5): 367-386. DOI: https://doi. org/10.1108/0070700710746786.

Borup, Jørn and Lars Ahlin. 2011. Religion and Cultural Integration: Vietnamese Catholics and Buddhists in Denmark. - The Journal of Nordic Migration Research 1 (3): 176-184. DOI: https:// doi.org/10.2478/v10202-011-0015-z.

Bledsoe, Brandon "Kál'lá". The Significance of the Bear Ritual Among the Sami and Other Northern Cultures. - Sami Culture. http://www.laits.utexas.edu/sami/diehtu/siida/religion/bear.htm (accessed December 1, 2017).

BHA $2012=$ British Humanist Association to the DEFRA consultation on Welfare of Animals at the Time of Killing. https://humanism.org.uk/.../1bha-response-to-defra-on-ritual-killing (accessed October 22, 2017).

Burack, Jacob A. and Louis A. Schmidt, eds. 2014. Cultural and Contextual Perspectives on Developmental Risk and Well-Being. New York, NY: Cambridge University Press. DOI: https://doi. org/10.1017/CBO9780511920165. 
Burns, Tom R. 2012. The Sustainability Revolution: A Societal Paradigm Shift. - Sustainability 4 (6): 1118-1134. DOI: https://doi.org/10.3390/su4061118.

Cesari, Jocelyne. 2013. Religion and Diasporas: Challenges of the Emigration Countries. Fiesole: European University Institute. http://interact-project.eu/docs/publications/Research\%20Report/ INTERACT-RR-2013-01.pdf (accessed December 1, 2017).

Diller, Jerry V. 2014. Cultural Diversity: A Primer for the Human Services. 5th edn. China: Cengage Learning.

Downing, Emma. 2015. Religious Slaughter of Animals. - House of Commons Library. http:// researchbriefings.files.parliament.uk/documents/SN07108/SN07108.pdf (accessed November 30, 2017).

ECHR = European Convention of Human Rights, Article 9. http://www.echr.coe.int/Documents/ Convention_ENG.pdf (accessed December 1, 2017).

Edgell, Penny. 2012. A Cultural Sociology of Religion: New Directions. - Annual Review of Sociology 38: 247-265. DOI: https://doi.org/10.1146/annurev-soc-071811-145424.

FAWA $33 b=$ Finnish Animal Welfare Act 33b. https://www.finlex.fi/fi/laki/ajantasa/1996/ 19960247\#L2-2P33b (accessed December 1, 2017).

Fiksel, Joseph. 2006. Sustainability and Resilience: Toward a Systems Approach. - Sustainability: Science, Practice and Policy 2 (2): 14-21. DOI: https://doi.org/10.1080/15487733.2006.11907980.

Finland Statistics. 2012. Migration 2011. http://www.tilastokeskus.fi/til/muutl/2011/muutl_2011_ 2012-04-27_en.pdf (accessed December 13, 2017).

Fraser, David. 1999. Animal Ethics and Animal Welfare Science: Bridging the Two Cultures. - Applied Animal Behaviour Science 65: 171-189. DOI: https://doi.org/10.1016/S01681591(99)00090-8.

Giordan, Guiseppe. 2014. Introduction: Pluralism as Legitimization of Diversity. - Religious Pluralism: Framing Religious Diversity in the Contemporary World, edited by Giuseppe Giordan and Enzo Pace. New York, NY: Springer, 1-12.

Grandin, Temple. 1992. Effect of Genetics on Handling and $\mathrm{CO}_{2}$ Stunning of Pigs. - Meat Focus International: 124-126. http://www.grandin.com/humane/meatfocus7-92.html (accessed November 30, 2017).

Gradin, Temple. 2010. Auditing Animal Welfare at Slaughter Plants. - Meat Science 86 (1): 56-65. DOI: https://doi.org/10.1016/j.meatsci.2010.04.022.

Grandin, Temple. 2013. Making Slaughterhouses More Humane for Cattle, Pigs, and Sheep. - Annual Review of Animal Biosciences 1: 491-512. DOI: https://doi.org/10.1146/annurev-animal-031412-103713.

Gregory, N. G. 2005. Recent Concerns about Stunning and Slaughter. - Meat Science 70 (3): 481491. DOI: https://doi.org/10.1016/j.meatsci.2004.06.026.

Hall, Elif Eroglu and Sevim Nurdan. 2016. Halal Food Consumption Intention by Turkish Immigrants. - International Journal of Business and Management Invention 5 (11): 36-40.

Hall, Edward T. 1966. The Hidden Dimension. New York, NY: Doubleday.

Hall, Edward T. 1976. Beyond Culture. New York, NY: Doubleday.

Hinman, Lawrence M. 2003. Understanding the Diversity of Moral Beliefs: Relativism, Absolutism and Pluralism. - Ethics: A Pluralistic Approach to Moral Theory. 3rd edn. USA: Thomson Wadsworth, 25-60.

Hisham, Abu-Raiya and Kenneth I. Pargament. 2015. Religious Coping Among Diverse Religions: Commonalities and Divergences. - Psychology of Religion and Spirituality 7 (1): 24-33. DOI: https://doi.org/10.1037/a0037652.

Hofstede, Geert. 1984. Cultural Dimensions in Management and Planning. - Asia Pacific Journal of Management 1: 81-99. DOI: https://doi.org/10.1007/BF01733682.

Jupp, James. 2011. Religion and Integration in a Multifaith Society. - Multiculturalism and Integration: A Harmonious Relationship, edited by Michael Clyne and James Jupp. Canberra: Australian National University Press, 135-150. 
Kavanaugh, Andrea L.; Debbie Denise Reese, John M. Carroll and Mary Beth Rosson. 2007. Weak Ties in Networked Communities. - The Information Society: An International Journal 21 (2): 119131. DOI: https://doi.org/10.1080/01972240590925320.

Kolan, Matthew and Kaylynn Sullivan TwoTrees. 2014. Privilege as Practice: A Framework for Engaging with Sustainability, Diversity, Privilege, and Power. - The Journal of Sustainability Education 7: 1-13.

Lambooij, E.; H. Anil, S. R. Butler, H. Reimert, L. Workel and V. Hindle. 2012a. Transcranial Magnetic Stunning of Broilers: A Preliminary Trial to Induce Inconsciousness. - Animal Welfare 20 (2011): 407-41.

Lambooij, E; J. T. N. van der Werf, H. G. M. Reimert and V. A. Hindle. 2012b. Restraining and Neck Cutting or Stunning and Neck Cutting of Veal Calves. - Meat Science 91 (1): 22-28. DOI: https://doi.org/10.1016/j.meatsci.2011.11.041.

Larsen, Joan Nymand and Gail Fondahl, eds. 2014. Arctic Human Development Report: Regional Processes and Global Linkages. Denmark: Norden.

Lavi, Shai J. 2014. Humane Killing and the Ethics of the Secular: Regulating the Death Penalty, Euthanasia, and Animal Slaughter. - UC Irvine Law Review 297. http://scholarship.law.uci. edu/ucilr/vol4/iss1/14 (accessed November 30, 2017).

Levinger, I. M. 1995. Shechita in the Light of the Year 2000: Critical Review of the Scientific Aspects of Slaughter and Shechita. Jerusalem: Maskil L'David.

Maslow, Abraham H. 1943. A Theory of Human Motivation. - Psychological Review 50 (4): 370-396. DOI: https://doi.org/10.1037/h0054346.

Nakyinsige, K.; Y. B. Man, Z. A. Aghwan, I. Zulkifli, Y. M. Goh, F. Abu Bakar, H. A. Al-Kahtani and A. Q. Sazili. 2013. Stunning and Animal Welfare from Islamic and Scientific Perspectives. - Meat Science 95 (2): 352-361. DOI: https://doi.org/10.1016/j.meatsci.2013.04.006.

Nakyinsige, K.; A. Q. Sazilia, I. Zulkifli, Y. M. Goh, F. Abu Bakar, A. B. Sabow. 2014. Influence of Gas Stunning and Halal Slaughter (No Stunning) on Rabbits Welfare Indicators and Meat Quality. - Meat Science 98 (4): 701-708. DOI: https://doi.org/10.1016/j.meatsci.2014.05.017.

Ngo, Hieu Van; Avery Calhoun, Catherine Worthington, Tim Pyrch and David Este. 2017. The Unravelling of Identities and Belonging: Criminal Gang Involvement of Youth from Immigrant Families. - Journal of International Migration and Integration 18 (1): 63-84. DOI: https://doi. org/10.1007/s12134-015-0466-5.

Pace, Enzo. 2014. Religion in Motion: Migration, Religion and Social Theory. - Changing Soul of Europe: Religions and Migration in Northern and Southern Europe, edited by Helena Vilaça, Enzo Pace, Inger Furseth and Per Pettersson. London: Routledge, 16-18.

Putzkoff, Irwin H.; Cho Byung-Ho and Oh Jin-Hwan. 2012. Animal Stress Results in Meat Causing Disease. http://omega77.tripod.com/meatandstress.htm (accessed December 1, 2017).

Qur'ân = The Holy Koran. 1983. Translated by Arthur J. Arberry. Oxford: Oxford University Press.

Rahman, Sira Abdul and Hassan Aidaros. 2012. Role of Veterinary Services and Islamic Religious Authorities in Improving Animal Welfare at Slaughter. - World Organisation For Animal Health. https://www.oie.int/eng/AW2012/presentations/PTT Session 2/2.4. Aidaros-Rahman. pdf (accessed December 1, 2017).

Rasmussen, Ole Rasmus and Lise Smed Olsen. 2014. Sustainable Development in the Arctic. Nordregio. http://www.nordregio.se/en/Metameny/About-Nordregio/NCM-Arctic-Co-operation-Program-Arktiskt-Samarbetsprogram/Sustainable-development-in-the-Arctic---TheNordic-Council-of-Ministers-Arctic-Co-operation-Programme-2012-2014/ (accessed December 1, 2017).

Reed, M. S.; G. Podesta, I. Fazey, N. Geeson, R. Hessel, K. Hubacek, D. Letson, D. Nainggolan, C. Prell, M. G. Rickenbach, C. Ritsema, G. Schwilch, L. C. Stringer and A. D. Thomas. 2013. Combining Analytical Frameworks to Assess Livelihood Vulnerability to Climate Change and Analyse Adaptation Options. - Ecological Economics 94: 66-77. DOI: https://doi.org/10.1016/j. ecolecon.2013.07.007. 
Rosen, S. D. 2004. Physiological Insights into Shechita. - Veterinary Record 154 (24): 759-765. DOI: https://doi.org/10.1136/vr.154.24.759.

Röver, Corinna. 2014. A Sustainable Arctic: Preconditions, Pitfalls and Potentials. - Konrad Adenauer Stiftung: 1-5. http://www.kas.de/wf/doc/kas_39168-544-2-30.pdf?161026150640 (accessed December 13, 2017).

Salamano, Germana; Antonio Cuccurese, Antonio Poeta, Enrico Santella, Paola Sechi, Valentina Cambiotti and Beniamino T. Cenci-Goga. 2013. Acceptability of Electrical Stunning and PostCut Stunning Among Muslim Communities: A Possible Dialogue. - Society \& Animals 21 (5): 443-458. DOI: https://doi.org/10.1163/15685306-12341310.

Schyff, Gerhard van der. 2014. Ritual Slaughter and Religious Freedom in a Multilevel Europe: The Wider Importance of the Dutch Case. - Oxford Journal of Law and Religion 3 (1): 76-102. DOI: https://doi.org/10.1093/ojlr/rwt046.

Shameem, Masud Iqbal Md.; Salim Momtaz and Ray Rauscher. 2014. Vulnerability of Rural Livelihoods to Multiple Stressors: A Case Study from the Southeast Coastal Region of Bangladesh. - Ocean \& Coastal Management 102 (A): 79-87.

Brunton-Smith, Ian; Jonathan Jackson and Alex Sutherland. 2014. Bridging Structure and Perception: On the Neighbourhood Ecology and Beliefs and Worries About Violent Crime. - British Journal of Criminology 54 (4): 503-526. DOI: https://doi.org/10.1093/bjc/azu020.

Singh, N. and J. Gilman. 1999. Making Livelihoods More Sustainable. - International Social Science Journal 51 (162): 539-545. DOI: https://doi.org/10.1111/1468-2451.00225.

Stajcic, Nevana. 2013. Understanding Culture: Food as a Means of Communication. - Hemispheres 28: 5-14. http://yadda.icm.edu.pl/yadda/element/bwmeta1.element.desklight-3b71a1ed-2c03499a-8884-ab5ec51e1f56/c/05-Stajcic_v01.pdf (accessed October 21, 2017).

Stevens, Stans, ed. 2014. Indigenous Peoples, National Parks, and Protected Areas: A New Paradigm Linking Conservation, Culture, and Rights. Tucson, AZ: University of Arizona Press.

Luthe, Tobias. 2014. Creating a Vision for Sustainable Arctic Communities. - Great Energy Challenge. http://energyblog.nationalgeographic.com/2014/01/10/creating-a-vision-for-sustainablearctic-communities/ (accessed December 1, 2017).

Valenta, Markha. 2012. Pluralist Democracy or Scientistic Monocracy? Debating Ritual Slaughter. - Erasmus Law Review 1: 27-41.

Yeasmin, Nafisa. 2013. Implementation of the EU Immigration Policy in the Barents Euro Arctic Region: Towards a Framework for Policy Analysis. - The International Year Book of Polar Law 5 (1): 603-640. DOI: https://doi.org/10.1163/22116427-91000138.

Yeasmin, Nafisa. 2014. Integration of Religious Minorities in the Finnish Part of Arctic: Justification on Community Sustainability. - Current Developments of Arctic Law 2, edited by Timo Koivurova and Waliul Hasanat. Rovaniemi: University of the Arctic Thematic Network on Arctic Law, 41-45.

Yeasmin, Nafisa. 2016. The Determinants of Sustainable Entrepreneurship of Immigrants in Lapland: An Analysis of Theoretical Factors. - Entrepreneur Business and Economic Review 4 (1): 129-159. DOI: https://doi.org/10.15678/EBER.2016.040109.

Zhang, Y.; A. Baral and B. R. Bakshi. 2010. Accounting for Ecosystem Services in Life Cycle Assessment II: Toward an Ecologically Based LCA. - Environmental Science \& Technology 44 (7): 2624-2631. DOI: https://doi.org/10.1021/es900548a.

Zoethout, Carla M. 2013. Ritual Slaughter and the Freedom of Religion: Some Reflections on a Stunning Matter. - Human Rights Quarterly 35 (3): 651-672. DOI: https://doi.org/10.1353/ hrq.2013.0040. 